\title{
The sustainable suburban high street: a review of themes and approaches ${ }^{1}$
}

\section{S. Griffiths, L. Vaughan, M. Haklay, C. E. Jones}

Bartlett School of Graduate Studies, UCL

Department of Civil, Environmental and Geomatic Engineering, UCL

\begin{abstract}
Whether suburbs are regarded as a distinctive feature of the contemporary urban landscape or as symptomatic of 'sprawl' the recent upsurge of scholarly interesting suburbia has done little to displace the dominant image of the suburb as primarily residential phenomenon. In a wide ranging survey of the academic literature, taking account of current developments in the policy debate relating to suburban regeneration and also drawing on research conducted by the Engineering and Physical Sciences Research Council's Towards Successful Suburban Town Centres project at University College London, this article argues for an approach to the suburbs that emphasises their importance as historical centres of diverse social and economic activity. The focus is on the 'typical' British suburban high street, regarded as a complex and dynamic socio-spatial entity facing particular challenges to its vitality and viability in the light of ongoing socio-economic change. It is suggested that an improved understanding of the relation between suburban society and the built form of suburban centres over time would lead to a fuller appreciation of the actual and potential contribution of the local high street to achieving sustainable built environments.
\end{abstract}

\section{Introduction}

In Britain, the term 'high street' carries cultural connotations of reassuringly small town or suburban neighbourhoods characterised by social stability and enduring local identity. According to the popular image, the high street functions as the communal hub; a place where near neighbours 'bump' into each other on their way to the post office, parents accompany children to the library and the elderly swap local gossip at the bus stop. Above all, the idea of the high street is associated with the presence of a wide variety of small local shops, ensuring easy pedestrian accessibility to everyday goods and services. Over the last three decades, this popular image of the 'typical' high street has become steadily less credible as the growth of out-of-town shopping and the tendency of corporate retailers to expand only into larger centres has undermined both the traditional independent high street trader and the smaller centres where they do business. At the same time, increased car ownership, changes in lifestyle, corporate restructuring in the retail and financial sectors and the arrival of internet

\footnotetext{
1 (C) 2008 The Authors, Journal Compilation (C) 2008 Blackwell Publishing Ltd, Geography Compass 2 (2008): 10.1111/j.17498198.2008.00117.x
} 
shopping, are among a number of factors that raise the question of whether the local high street has any future at all when the socio-economic conditions associated with its historical development appear, in many respects, no longer to apply. This article explores these ideas by suggesting that the future success of the suburban high street is dependent on its characteristic capacity for resilience in the face of socio-economic change becoming increasingly recognised and valued by planners and policymakers.

As yet, no definition of 'sustainability' has emerged that geographers are widely agreed on. Rydin (1999) has noted that within environmental discourse alone there is limited agreement between competing perspectives. The multi-functional nature of suburban town centres serves only to confuse the issue further by bringing to bear the wide range of social and economic interpretations that are available. As a consequence of the lack of clarity in the literature, this article will emphasise ‘adaptability’ rather than ‘sustainability' as such, on the basis that it is a term better suited to identifying those generic socio-spatial factors favourable to the long-term social and economic health of the high street. Sustainability, in other words, is broadly interpreted as that relating to the persistence of socio-economic activity over time. The emphasis on 'sustainability as adaptability' in regard to suburban centres is justified by the (rarely acknowledged) complexity of the high street environment itself. At issue here, therefore, are less the particular strategies that might improve the sustainability of a centre in a variety of ways, than the simple contention that high streets characterised by a diverse range of socio-economic activities provide the essential local milieu in which such strategies might be successfully implemented.

These concerns are reflected in the themes covered by this article that together provide a broad critique of one-dimensional notions of how a 'successful' suburban town centre should be defined. Rather, the focus is on the high street and small suburban centre as distinctive socio-spatial environments whose potential contribution to the wider sustainability agenda is inadequately dealt with in the existing literature. Section 2 is concerned with the historical development of the 'typical' suburban centre in Britain and how it differs from its North American equivalent, both in terms of built form and the protection afforded by government planning regulations in the UK. Section 3 makes the case that gauging the success of a high street by its retail functions alone is to neglect the range of consumer, commercial and communal functions that suburban centres support. Section 4 examines the numerous challenges facing the contemporary high street by offering a critique of the 'clone town' 
thesis. Section 5 combines social and spatial themes in a discussion of high streets as 'dual function’ public spaces, constituted as both places and links between places. A series of mapped visualisations of the Greater London suburb of Whetstone are presented to illustrate how the historical spatial form of a suburban high street relates to different categories of contemporary land use. Finally, some conclusions are drawn regarding the relationship of pedestrian movement and long-term sustainability in suburban town centres

\section{Suburbia, sustainability and the high street}

Definitions of suburbs and taxonomies of suburban settlement types abound in the literature (e.g. Gwilliam et al. 1999; Harris and Larkham 1999; Thorns 1972; Urban and Economic Development Group [URBED] 2002). This variety reflects the practical difficulty of achieving a precise classification of a phenomenon that is logically inseparable from, though not synonymous with, the urbanisation process itself and as historically contingent as to the exact form it takes. For this reason, Hinchcliffe's $(2005,900)$ identification of the suburb's

necessary relation to the city as its essential distinguishing feature seems preferable as a more generic definition. She argues that the 'monofunctional' and 'residential' character of the suburbs are the most commonly agreed aspects of contested definitions but that this very consensus may have 'distorted our conception of the suburb' (Hinchcliffe 2005, 899). It is interesting to reflect, in a contemporary context, on the form this distortion might take. Could an alternative perspective on the suburbs that emphasises their role as local centres also find that their perceived 'monofunctionalism' in fact conceals rather more variegated social activities?

A historically informed approach suggests that this might be the case. Certainly, it is generally true that suburban development in the UK took place around pre-urban nucleated settlements that were favourably located in relation to road or railway transport links (Rowley 2006; Whitehand and Carr 2001). In many cases, such settlements already possessed distinctive identities as places before they were clearly 'suburbanised' within a larger urban region. This historical growth trajectory provides an important corrective to the North American dominated literature of 'sprawl’, ‘edge city’ or even 'edgeless city’ (Duany et al. 2000; Garreau 1992; Lang 2003). Here, suburban development is characterised as giving rise to a decentralised environment that is essentially 'disurban' in the sense that it lacks the compactness traditionally associated with European urban cores. While similar trends are also 
evident in Europe, they should not be regarded as typical, not least because the suburbanisation process was well advanced before the mass market for cars became established in the second half of the 20th century (Tiesdell 2002). In the UK, suburbanisation has tended to lead to the expansion of settlements relatively low down the urban hierarchy, rather than 'edge cities’ as such, and sprawl has been further restricted by extensive planning legislation, for example, in the legal protection of designated 'green belts' and the more recent advocacy of brownfield over greenfield development (Breheny 1996).

The pattern of suburban growth in Britain focuses attention on an important distinction between the various branches of Anglo-Saxon suburbanism that, in other respects, share many similarities (Clapson 2003; Harris and Larkham 1999). The nearest American equivalent to the British 'high street' is 'main street' but this can hardly be regarded as characteristic of the suburban periphery of American cities where the large-scale shopping mall has a longer and more fundamental relationship with the history of suburban expansion than in Britain. In British suburbs, by contrast, the identity of a 'high street' as a local centre hosting a variety of commercial and communal functions embodies a degree of continuity in land use with the pre-urban settlement form.

The historical continuity between the village, the small town and the suburban high street in Britain should be considered as a key element in any definition of neighbourhood sustainability, because it provides a model of how local centres have adapted to change rather than been swept away by it. Where such centres have continued to function reasonably well over time they provide a natural bulwark against 'sprawl' by making denser residential and brownfield development more attractive. In both the UK academic and policy-orientated literature, it has become conventional to classify the persistence of 'everyday' socioeconomic activity in traditional suburban centres in terms of their 'vitality' (a good indicator is the amount of pedestrian activity) and 'viability' (referring mainly to the ability to attract investment) (Department of the Environment, Transport and the Regions [DETR]/Welsh Office 1993; Office of the Deputy Prime Minister [ODPM] 2005; Ravenscroft 2000; URBED 1994). Although much further detailed research in this area is needed, there can be little doubt in general that the vitality and viability of the high street are interrelated, because high rates of footfall should help to sustain communal life and commercial potential by making the centre more attractive to those businesses prepared to pay a premium for the opportunity to cash in on passing trade. In this respect, suburban high streets could be considered as 
examples of what Hillier (1999) calls 'live centres', that is public space that disproportionately attracts movement, whether pedestrian, vehicular or both, owing to a high degree of spatial accessibility within the urban grid.

Transport planners, thinking in terms of origins and destinations rather than the spatial properties of the street network, are more likely to emphasise the attractiveness of particular land uses, such as the site of a leading supermarket or transport node, to explain the presence of movement (e.g. Tolley and Turton 1995). In fact, both forms of movement attraction are clearly interrelated - it is surely not by chance that commercial activity of various types has tended to agglomerate in and around a particular central street - but the presence of a major attractor will also exert a strong multiplier effect on the quantity of movement that occurs there. In this respect, the historical British high street can be characterised as an 'unplanned central place' that functions both as a route of 'through movement' within a wider region and as a destination in its own right. It is distinguished from the North American 'main street' not only by its typically suburban location but also because its role as a centre of community activity clearly differentiates it from retail strip developments that are located along major highways and transit routes.

Kochan $(2007,11)$ has commented that the suburbs are generally believed to be socially and environmentally unsustainable owing to their relatively low densities in comparison with urban areas. Considering that some $84 \%$ of the UK population live in areas classified as suburban and that this figure is set to increase as people continue to show a preference for living at greater distances from the urban core (a phenomenon referred to by Champion as the 'population cascade') it is evident why the question of suburban sustainability is gradually moving up the UK policy agenda (Champion 2005; Echenique and Homewood 2003). At a strategic level, the population cascade has major implications for national planning policy. Rapid suburbanisation is likely to encourage an expansion of out-of-town retail (and office) development by providing it with a catchment, resulting in the rapid increase of everyday car use associated with North American suburbia (Guy and Lord 1993). Maintaining the vitality and viability of local and district suburban centres, therefore, is important if future suburban development in the UK is not to be characterised by 'sprawl'. The assertion of a distinction between 'suburb' and 'sprawl' in itself implies how historical suburban centres increasingly need to be categorically distinguished from more contemporary urban forms, driven mainly 
by residential expansion, that some scholars have characterised as being 'post-suburban' (Phelps et al. 2006).

The publication of the report of the Urban Task Force (UTF 1999)(DETR) signified an acceptance by the UK government that increased car use, pollution, depopulation, social exclusion and community breakdown were related phenomena associated with the effects on urban cores of several decades of decentralisation endorsed by government policy. The report represents a firm rejection of the laissez-faire planning policies that characterised Margaret Thatcher's Conservative governments of the 1980s. During this period, developers of large out-of-town developments were given a relatively free reign, especially within the special enterprise zones established as a market-led response to a rising inner-urban crisis exacerbated by the effects of unemployment, riots and depopulation. Large-scale developments such as Sheffield's Meadowhall Centre that were established under this scheme often had the affect of accelerating city centre decline, at least in the short term (Rowley 1993). Seen from this perspective, the report of the UTF in 1999 marked a significant policy shift from a centrifugal, or suburbanising, model of urban development to a centripetal, or intensification, model of urban regeneration with an emphasis on higher residential densities and brownfield development. While the UTF was mainly concerned with blight in urban centres, this change in orientation also had implications for smaller, suburban centres.

The shift had been anticipated by the gradually changing emphasis of the UK government's Planning Policy Guidance 6 (PPG6) between 1988 and1996. This regime was responsible for providing local planning authorities with guidelines on the regulation of retail developments. The light regulatory stance of the initial PPG6 (1988) was superseded in 1996 by a 'plan-led' policy that sought to uphold the integrity of a well-defined hierarchy of urban centres from major city centres down through town, district, local and village levels, as a regulative check against the proliferation of out-of-town suburban developments (DETR 1996). PPG6 (1996)introduced the notion of the 'sequential test' that put the onus on retail developers to prove that their plans for off-centre sites could not be accommodated within existing town centres, or adversely effect them.PPG6 was replaced in 2005 by Planning Policy Statement 6 (PPS6) (ODPM 2005). PPS6 aspires to establish sustainable development as the cornerstone of the government's planning policy for town centres by extending the 'plan-led' approach beyond a focus on retail towards a more generalised strategy of town centre management. 
However, despite the apparent consolidation of PPG6 by PPS6, it should be noted that in 2006the Treasury sponsored Barker report appeared to water down the restrictions on new out-of-town retail centres by removing the stipulation that would-be developers must demonstrate a local economic 'need' (Barker2006, 7). The effects of this change in policy are yet to be clear.

One difficulty with the original report of the UTF is that it fails to distinguish between urban centres and suburban centres. In the follow-up report (UTF 2005), there is limited recognition that many suburban and neighbourhood centres have yet to benefit from the renewal associated with the much heralded 'urban renaissance'. However, it remains a general criticism of government policy that the difficulties facing suburban centres are not acknowledged as distinctive or significant in their own right when compared to the different kinds of problems facing inner-city areas. Indeed, there is some danger that the 'plan-led' approach may work against the interest of smaller centres by concentrating investment higher up the urban hierarchy. This helps to explain why, when the question of suburban sustainability is addressed by central government, the focus tends to be on its residential functions, as in the Office of the Deputy Prime Minister's Sustainable Communities policy (ODPM 2003).

On the whole, the planning policy agenda for suburban centres has been developed outside central government agencies by consultancies, charitable organisations and academic institutions working independently or alongside local authorities. Among these, the URBED, the Joseph Rowntree Foundation (JRF) and the In Suburbia Partnership have made particularly significant contributions (Gwilliam et al. 1999; Jones et al.2007; Kochan 2007; In Suburbia Partnership 2002, 2005; URBED 1994, 2002, 2004). This body of research is building a consensus around the idea that suburban and small town centres are distinctive environments combining a range of commercial and communal activities. They point out that suburban centres are also experiencing some difficulties, such as increased congestion and fear of crime that are traditionally associated with more urban centres. Another theme in the literature is that as diverse centres of economic activity within larger city regions, suburban centres also have the potential to contribute to greater urban sustainability overall, for example, by providing local employment, but that this potential is not being fulfilled (Maguire 2004). 
The emerging consensus is summarised in a recent report by Kochan (2007) for the JRF: Achieving a Suburban Renaissance. This report draws on research by the Engineering and Physical Sciences Research Council(EPSRC) City Form project (City Form 2003-2007) and the World Wildlife Fund (Francis and Wheeler 2006) to argue that there is a case to be made for both the social and environmental sustainability of suburban life in comparison with denser and less green urban environments that are more likely to suffer from social malaise, higher ambient temperatures and are less able to take advantage of new environmental technologies such as roof-based sources of power generation. Kochan's perspective adds credibility to the view that for 'sustainability' to mean anything it must be made to work in the suburban environments where most people actually choose to live (Marshall 2006). It is precisely to avoid the re-emergence of urban problems in the suburbs, and the misapplication of urban solutions to suburban situations, that a bespoke sustainability agenda for suburban centres is required. There is some evidence that this is already happening. For example, in a report commissioned by the Greater London Authority (GLA) Semi-Detached: Reconnecting London's Suburbs (GLA 2007), there is clear evidence that a policy agenda is emerging that engages with the suburbs as multifaceted environments functioning as centres of work, leisure and community.

The UK government's emphasis on the vitality and viability of town centres has given fresh impetus to the tradition of urbanism associated with Jacobs, Whyte and Appleyard, with their emphasis on the importance of maintaining accessible, human scale, urban environments able to accommodate a diversity of street life (Appleyard 1981; Jacobs 1961; Whyte 1980). In another recent piece of JRF commissioned research Rediscovering Mixed-Use Streets, Jones et al. (2007) argue that the principles of modernist planning served to undermine the characteristic mix of the traditional high street by deploying large, isolated blocks to separate buildings from streets, traffic from pedestrians and different land uses from each other. The authors, taking care to avoid cultural specificity, prefer to use the term 'mixed-use street' to 'high street' although it is clear that they view both terms as more or less synonymous. Their study focuses on smaller neighbourhood centres located just beyond the urban core. They define 'mixed-use' at the fine grain of the street where the footprint of buildings is typically small and contains a wide range of retail, commercial, public sector and residential land uses 'intermingled' in the same vicinity ( Jones et al. 2007, 1). The report asks whether, far from being an outdated mode of urbanism, the mixed-use street has lessons for 21st century planning in the model it provides of the kind of local public space that different kinds of 
people visit on a regular basis. The vitality of the high street's street life is an essential but sometimes overlooked prerequisite of sustainability because, where the public space of the suburban centre is perceived to have failed, the privatised space of the suburban shopping mall, or even the internet connected apartment block, is likely to offer amore attractive environment for combining social and consumer activity (Madanipour 2003, 213-217).

Jones et al. (2007) draw on three detailed case studies as the basis for reassessing the potential of mixed-use streets according to a broad definition of sustainability that includes both social and environmental factors. All three cases are located in different cities and lie relatively centrally but beyond the urban core. The focus of their research is the experience of the high street for local users; an approach consistent with the UK government's 'liveability agenda' that addresses how people feel about their everyday environment (ODPM 2002, 2003). Whereas government reports have tended to focus on the availability of open space and the quality of the residential environment, the JRF report asserts the importance of mixed-use streets to the quality of communal life. It identifies how each high street area contributes to the vitality and viability of the local centre despite the long-term absence of a planning regime adequately favourable towards them. The contributions include: encouraging more sustainable travel, helping to support local businesses, facilitating social inclusion by offering a relatively safe and accessible environment to a diverse population, and offering a natural locus for neighbourhood identity (Jones et al. 2007, 105-107). This leads the authors to conclude that 'mixed-use local high streets are adapting to the consumer and citizen needs of the 21st century' (Jones et al. 2007, 105).

It is notable that this reference to 'adaptability' in the context of mixed-use streets also occurs in the reports of the UTF, for example, in the assertion that sustainable built environments should be 'adaptable to change' (UTF2005, 2). In contrast, the argument in this article is that adaptability is better understood as a condition of sustainability rather than an outcome and is more likely to reside in the relatively generic socio-spatial factors that explain the historical vitality of the high street rather than in those planning interventions that undermine them. There is a sense in which an emphasis on adaptability might be thought to duck the issue of sustainability altogether by appearing to tacitly endorse a laissez-faire approach to suburban development. Such an argument misses the important point that in identifying 'what works' for local people in an everyday sense, urban geographers can help planners and designers work with, rather than against, the historical 'grain' of suburban centres. 
Jones et al. (2007) suggest what 'adaptability' might mean in practice by identifying a number of challenges faced by the mixed use street and then proposing how improved policy and design could enhance long-term sustainability. Chief among the challenges cited are: the priority given to traffic over pedestrians, creeping gentrification, environmental degradation, lack of public lavatory facilities and the absence of an integrated management strategy for the public realm (Jones et al. 2007, 107-109). The broad scope of the issues raised by the report is noteworthy because it is a legitimate criticism of some micro-scale and design-led approaches to town centre improvement that wider social policy implications are neglected. A rapid increase in middle-class 'gentrification', for example, highlights the existence of a planning regime favourable to regeneration; however, whether this regime benefits or displaces the existing residential population is a matter of some debate (Lees et al. 2008, 195-238). Increased residential densities in suburban centres (consistent with the goal of the UTF to promote brownfield development) might be assumed to bring benefits to the suburban high street but where these are intended primarily for commuters to the city centre, the extent of this benefit is far from being clear. By drawing attention to the wider policy context, Jones et al. make the point that the vitality of mixed-use streets is a necessary rather than a sufficient criterion of sustainability. It follows that the authors' policy recommendations are aimed at developing a flexible framework in which the historical qualities of the mixed-use street as a public space can be allowed to thrive under various socio-economic conditions, rather than to promote a particular image of the 'traditional' high street or the 'ideal' high street of the future.

In noting the historical character of the UK mixed-use street as both a place in its own right and a link within a regional movement system, Jones et al. $(2007,11)$ suggest that this distinctive 'dual function' should be acknowledged at the strategic planning level as providing the key organising concept around which the different (and changing) needs of the pedestrian and motorist can be balanced. Other recommendations in the report address the need for more coordination between stakeholders, better information gathering and increased investment in smaller, district centres. The authors emphasise the constitution of the traditional high street as a complex socio-spatial environment which, in the variety of street life and land uses it hosts, is anything but 'monofunctional'. By emphasising the importance of mixed-use street environments to the quality of life in suburban areas the authors of Rediscovering Mixed-Use Streets have made an important contribution. 


\section{Not just retail: the high street as a source of socio-economic diversity}

The UK government's PPS6 states that the diversity of town centre land uses is indicative of their 'vitality' and 'viability'. However, this emphasis on diversity is rarely reflected in the town centre literature and policy documents that usually focus on retail at the expense of other activities. This bias towards retail is exemplified by the tendency of planners, policymakers and academics to rank town centres according to the presence or absence of retail functions rather than any other sort of activity, and to privilege chain stores over independents when doing so on the basis that these provide a better comparative index (Hall et al. 2001; Reynolds and Schiller 1992). This tendency can be explained by the relative availability of retail data, which provides an intuitive basis for assessing urban scale, and the demand of the retail industry itself, which draws on such research to identify gaps in market coverage. It is also consistent with the UK government's planning policy, which is concerned to ensure that the scale of new retail developments is proportional to the size of proximate centres.

The lineage of the hierarchical ranking of centres can be traced back to the Christaller's Central Place Theory [1966 (original 1933)]. However, Christaller’s study took a much broader view of goods and services than the subsequent concentration on retail activities would suggest. In planning terms, a retail-based ranking system naturally reinforces the visibility of the larger centres to inwards investors. This is consistent with a recent report by the British Council of Shopping Centres (2004) that suggests that smaller suburban centres are increasingly lagging behind larger ones. A retail-centric view of suburban centres threatens to create a vicious circle in which the economic vulnerability of smaller centres is continually reinforced by their relative invisibility in policy and investment terms. This apparently self-perpetuating process is likely to undermine the long-term economic viability of suburban high streets.

It is desirable that alternative ranking systems are developed to capture the diverse range of consumer, commercial and communal functions that town centres serve. Ravenscroft (2000) has warned that too exclusive an emphasis on retail investment is unlikely to capture those aspects of town centre activity, such as leisure and catering, that are more explicitly dependent on ‘vitality’ (by which he generally means footfall) for business. He argues against 
simplistic assessments of town centre 'health', especially where these are closely tied to the value of commercial property.

A broader view of what contributes to the health of town centres might eventually lead to the downplaying of property in favour of a more inclusive approach, in which all types of use can find their place and make their contribution. (Ravenscroft 2000, 2548)

A definition of economic diversity has been attempted by the DCLG's (Department of Communities and Local Government, previously the ODPM) town centres project (DCLG 2002). Diversity was measured as a count of the total number of different jobs in the town centre. The retail, leisure, service and office sectors were included in this total; the manufacturing sector was excluded (Lloyd et al. 2003, 279). In fact, industry was a negative indicator of town centeredness, because it was the assumption of the study that the presence of industry pointed to decentralised activity. The omission of industry is understandable in this context, yet it is also indicative of a widespread tendency to associate high street activity exclusively with a retail or services presence rather than evaluating its potential for sustaining a diversity of interdependent everyday activities. Where a modern industry is neither a source of pollution nor disturbance, there seems no a priori reason why it should not also contribute to town centre vitality.

Wherever suburban centres are viewed exclusively in terms of retail their various roles as places of work and community activity are easily marginalised. In Greater London, it is certainly true that the suburbs have been adversely affected by the rapid decline of traditional manufacturing industry from the 1970s. This relates to a widespread concern that the large concentration of employment in central London, combined with its increasing distribution around the M25 ring, is to the detriment of the city's outer suburbs (URBED 2002). On the other hand, the DCLG's town centres study shows that suburban town centres remain important generators of local employment (DCLG 2002). The significance of suburban centres as workplaces relates not only to the viability of the centre itself but also to the cityregion as a whole in helping to reduce car use and ease pressure on the public transport infrastructure that connects centre and periphery (Maguire 2004).

The sustainability of diverse socio-economic activities in the suburbs is likely to be facilitated by their proximity to a successful mixed-use high street. Vaughan (2006) has argued that the urban structure of the outer London suburban town of Borehamwood, with its central spine 
along the high street of Shenley Road, means that local workers, incoming commuters and residents utilising community facilities are all able to participate in the civic and economic life of the suburban centre. The easy accessibility of Borehamwood centre, she argues, has helped to create a social mix that has enabled the suburb to continue 'working' as a place despite its experience of ongoing social change.

Jones et al.'s (2007) report for the JRF provides further support for the view that an accessible suburban high street facilitates a socially sustainable intermingling of demographic profiles and activities. The study found that the ethnicity and age profiles of those present on mixed-use streets generally reflected the profiles for the areas overall. Consistent with the findings of other research, the presence of these different groups was highly variable according to the time of day at which the survey was conducted (e.g. Bromley et al. 2005). Most of those surveyed for the report had travelled to the high street on foot. Although a large majority (approximately 40-70\%across the cases) gave shopping as the main reason for their trip, other reasons included: living nearby, working, studying, visiting friends or family, passing through, leisure, eating out and attending religious events. These reasons were all well represented in the survey overall and provided a good picture of the complex combination of activities taking place on or near a mixed-use street at different times of day (Jones et al. 2007, 57, 68). Of course, such activities should not be regarded as mutually exclusive; a trip to the high street might involve both shopping and visiting a nearby friend on the way back from work. This potential 'synergy' (in the sense of the whole being more than its parts; Ashworth 1997, 127) between diverse social activities means that it would be a mistake to conflate the vitality of the high street simply with the presence of retail; it is just as likely that the presence of retail reflects a rather more generic ability of high street environments to sustain a diverse range of activities.

Vaughan's pragmatic analysis of Borehamwood anticipates Kochan's caution against rose or possibly sepia - tinted images of mixed-use suburban centres. He argues that the 'idyll' of a mixed-use urban village 'imagines residents living in their villages and walking to work' and can hardly be accepted as a norm given the heavily residential nature of the suburbs (Kochan 2007, 42). Rather than retreating into misplaced nostalgia, the challenge for urban geographers, designers and planners is to identify those niche areas in which suburban employment and community activities might flourish and assist them in taking advantage of synergies that may arise from the high street's 'mix' of activities. With property prices 
currently high, there is great pressure on existing office and retail space to be converted to residential use and this presents suburban centres with a problem in terms of office availability; however, this situation might change under different economic conditions (Maguire 2004). A report from F.P.D. Savills quoted by Kochan suggests that increased provision of office space aimed at small-scale local businesses would be the most likely way to tap commercial demand in the suburbs (Kochan 2007, 43).

Other possibilities for the improvement of suburban centres include taking advantage of changes in working practices, for example, the increasing incidences of working from home and teleworking. The Labour Force Survey suggests that at the end of the last century approximately $25 \%$ of the working population worked at home at least some of the time and that this was evidence of a growing trend (Felstead et al. 2001). However, it is clear that the overall picture is extremely variegated and certainly does not conform to the popular image of the technologically empowered, high-salaried teleworker, who is revealed as something of a cliché. If the suburban high street is to take advantage of these new lifestyle and employment trends then a great deal more research into the possible effects of working from home will be necessary. Such research might consider whether there is any evidence of demand for social-working environments situated 'between the home and the office' that could be supplied by serviced short-term hire offices or other practicable arrangements; it could also consider the extent to which the suburban 'niche' is well placed to exploit such opportunities.

\section{4. 'Clone Town Britain' and its discontents}

In an English context, the history of the suburban high street is correctly placed within a tradition of small town urbanity with strong roots in what Borsay has termed the 'urban renaissance' of the 18th century. This period was associated with the improvement of the built environment, the gradual separation of production and consumption and the rise of a more consumer orientated and leisured society (Borsay 1989; Stobart et al. 2007). The part of town associated with shops and shopping formed an important part of 18th-century urban culture and began to compete successfully with traditional forms of retail such as the market and fair as an 'everyday’ activity (Fowler 1998). In many cases, the high street shopping area developed around the site of the old market shambles, meaning that its association with the communal and commercial heart of civic life can, from a contemporary perspective, seem 
virtually immemorial. It is perhaps for this reason that the fate of the traditional high street has become such a contentious and politicised area of social policy. The debate is dominated by the high street's alleged role as the 'proper' centre of retail activity and tends to emphasise one of two related themes: first, the centrifugally orientated 'retail revolution' associated with the growth of North American style out-of-town shopping centres and retail parks from 1980s, and second, the subsequent, centripetal process of chain shops and national department stores replacing independent retailers on the high street.

The challenge posed by out-of-town shopping centres to the socio-economic dynamics of the traditional high street is a key reference point in the academic and policy literature on town centres (e.g. Bromley and Thomas 1993; Dawson 1988; Gransby 1988; Gwilliam et al. 1999; Jones et al. 2007; Kay 1987; Schiller 1988; URBED 1994; Wrigley and Lowe1996). Guy (1988) argues that 'convenience' retailers who sell everyday food and household items are less well positioned to compete without-of-town retailers than town centre 'comparison' shops that sell specialist consumer goods and can also offer the consumer an alternative retail 'experience'. Whereas convenience shopping is more typical of suburban areas, comparison shopping is most concentrated in major town centres - suggesting how the suburban high street suffered disproportionately from the decentralisation of retail. He notes that, as a consequence of off-centre shopping, the economic, social and cultural linkages between the local shop and the customer as a 'locus for exchange of information' has been 'significantly although not completely disrupted' (Guy 1988, 954).

It is important to recall that the 'retail revolution' in the UK followed an earlier phase of postwar development that had seen the rapid construction of small-enclosed 'shopping centres', or precincts, in many of Britain’s town centres. From 1965 to 1980, 315 out of 387 such precincts were situated in town centre locations, many of these in the suburbs (Bennison and Davies 1980, 15). This is a trend that continued from the later 1980sas planning restrictions on out of town developments gradually tightened. These suburban shopping precincts have a mixed record of success and have frequently become sources of economic and physical blight. Nevertheless, local shopping centres and small retail parks located in and around the traditional high street have an important role to play in ensuring their future viability and vitality. Further research is needed in order to establish how the high street and local shopping centre are best integrated into the overall design of the town centre. In any case, there is little doubt that the dual impact of retail decentralisation and the entry of larger 
supermarkets into the local market for convenience foods (often within a shopping precinct or centre located on or just off the high street), has had a significantly deleterious effect on the traditional high street shop. One recent parliamentary report quotes research claiming that they are closing down at the rate of some 2000 a year (All-Party Parliamentary Small Shops Group [APPSSG] 2006, 8).

The impact of out-of-town developments should not be regarded as restricted to purely shopping related or daytime activities. The relocation of suburban retailers to out-of-town sites and office activity to business parks located along major transit corridors also has implications for employment in those traditional suburban centres that appear to be caught between the pull of the metropolitan centre on one hand and the dynamism of 'edge city' locations on the other. A recent report on the condition of London's outer suburbs has described this as an 'employment trough’ (Potts et al. 2007).

The construction of out-of-town entertainment multiplexes has also had an effect on the evening economy of the suburban high street, not least in the decline of the local cinema. Hubbard (2002) argues that the decentralisation of cinema going associated with the rise of the multiplex is symptomatic of the post-modern city in which urban leisure practices have become balkanised into a 'patchwork of consumer groups and areas, with little meaningful contact between them' (p. 1257). However, while acknowledging the many cultural changes that have undermined the traditional image of the high street, it is also important to bear in mind, as Jones et al. (2007) and Vaughan (2006) have argued, its continuing relevance as the public space through which a significant proportion of Britain's sizeable suburban population are able to access a range of consumer, commercial and community services.

The difficulties faced by the traditional high street as a consequence of out-of-town developments is politically sensitive, because it undermines what most policymakers agree is one of the key indicators of neighbourhood sustainability. This is the accessibility to services and amenities local centres provide to socially disadvantaged members of society; those with very limited incomes and restricted personal mobility, that Westlake has referred to collectively to as the 'disadvantaged consumer' (Westlake 1993; see also GLA 2007; Jones et al. 2007; Potts et al. 2007). Such groups disproportionately include the young, the elderly, parents with children, ethnic minorities and women. In the past, women were more likely to be caring for children and working in lower-paid jobs 'closer to home' and, despite changes 
in many women's lifestyles, the evidence is that this is still likely to be the case (Felstead et al. 2001; Madden 1981).

Nonetheless, an increase in the number of women working (and, consequently, of dualincome families) has led to a reorganisation of shopping patterns with major implications for traditional high streets, although the full effects of these changes are far from clear (Giles 2004; URBED 1994; see also Brewis 2004). It is quite possible for women to participate in the life of the suburban high street as workers as well as consumers. However, difficulties with managing childcare are likely to take women away from the high street if there is insufficient local proximity between the locations of workplace, childcare, town centre and home (McDowell et al. 2006). Moreover, where fear of crime is high, women may feel that the car and the shopping centre offer them increased security in comparison with a walk to the high street. The shopping centre offers one ready solution to consumers who may feel insecure in public space, although car journeys may also be undesirable in the absence of well-designed car parking facilities at the destination (Oc and Tench 1993, 165-166). Recent preliminary research into the location of crime at the fine grain scale of the street in an inner London borough has suggested that secure high streets may be associated with the accessibility of nearby residential areas that lend such centres a 'residential culture' (Hillier and Sahbaz 2005, 477).

Research in the UK has shown that people are inclined to think negatively of graffiti in a town centre, which is perceived a sign of neglect (Oc and Tench 1993, 164-165). The UK government's drive to eliminate crime in town centres as part of its strategy for urban regeneration has led to a dramatic increase in the presence of surveillance technologies such as closed circuit television cameras on Britain's high streets - in 2004 there were an estimated 2.5 million (Neyland 2004). A related anti-crime strategy, imported from the USA, is 'zero tolerance policing', premised on the notion that where urban space appears to be 'unowned', relatively small acts of vandalism can rapidly produce 'no-go' areas. However, as Raco (2003) has argued on the basis of his work on Reading, local police rarely have the resources or the political will to implement a zero-tolerance policy effectively, preferring instead to adopt design-led solutions to crime reduction accompanied by the strategic identification of high-priority areas for high-visibility policing. In any case, the level of resources that can deliver 'zero-tolerance' policing are more likely to be assigned to major 
city centres than to the low profile suburban centres with which they are competing for investment (Belina and Helms 2003, 1862).

The rise of out-of-town and edge-of-town shopping centres and the impact of a steadily increasing corporate retail presence on urban and suburban high streets have been scathingly documented in two pithily labelled series of reports by the New Economics Foundation (NEF):Ghost Town Britain and Clone Town Britain (Ironically, it is likely that planning restrictions on out-of-town retail parks have had the effect of increasing large format and chain retailer's interest in maintaining a high street presence). Ghost Town Britain II (2003) (subtitled 'death on the high street') compiles a formidable array of secondary evidence to show how corporate restructuring is leading to the systematic disappearance of traditional town centre functions such as banks, post offices and pubs. However, it should be pointed out that most banks, post offices and pubs are themselves managed by national or multinational corporations. According to the APPSSG (2006), 32\% of Britain's post offices and 25\% of its banking network has disappeared within the last two decades - a reduction that is likely to have affected rural and suburban areas the hardest (p. 37). The gradual disappearance from the high street of basic retail and commercial services means that for the disadvantaged consumer, the suburbs run the risk of becoming places where local access to good quality food products and financial services is increasingly limited. It is perhaps counterintuitive to think of suburbia as an area of financial exclusion or as constituting a 'food desert', but where the local high street is in decline this will become increasingly likely, especially among people in vulnerable social groups and where the provision of public transport is inadequate. Wrigley (2002, 2032) has noted that less affluent suburban estates, as well as inner-city ones, have experienced a steep decline in the number of local food shops since the 1970s.

The NEF reports argue that the relatively recent but extremely rapid expansion of supermarket chains into high street locations has led to increased rents and precipitated the decline of the independent convenience shop and essential services. At the same time, public open spaces and civic buildings such as community halls are often left in dire need of investment. The reports make the case that these losses to the high street are fundamentally unsustainable because they generate more car-based travel, undermine local jobs, local products, civic identity and the access to basic financial services on which day-to-day community life depends. In the context of retail activity, the bleak picture painted by Ghost 
Town Britain is largely reinforced by the findings of the APPSSG that expressed the fear that 'many small shops across the UK will have ceased trading by 2015 with few independent businesses taking their place' (APPSSG 2006, 6).

Arguing in a similar vein, the NEF report Clone Town Britain (2005) launched a swingeing attack on what the authors believe is the corporate exploitation and homogenisation of historical British urban centres. It argues that corporate profits are fed to global headquarters rather than circulated locally within the community. The report gives the result of a survey the NEF conducted of 130 suburbs and small towns which it classifies as 'clone towns' (55), 'border towns' (32) and 'home towns' (43). These labels were assigned on the basis of a range of criteria used to determine the extent to which the centre was characterised by corporate chains or independent local retailers. The results justify the claim of the study to be reporting on the ‘death of diversity' (NEF 2005, 5).

A number of criticisms could be levelled at the NEF reports that are deliberately polemical in tone and unequivocal in their extrapolations from the data. Sometimes, one might be forgiven for thinking the extravagant rhetoric appears to disguise a certain wistfulness for the 'good old days' of the butcher, the baker and the candlestick maker. There is also a striking coincidence of 'home towns' with small, affluent centres or fashionable inner-city locations that strongly hints at the cultural preferences of the authors - but also begs some interesting questions about why this should be the case. Might it be (somewhat ironically) that the gentrification process typically associated with inner-city neighbourhoods is becoming increasingly evident in more peripheral suburban centres where these provide alternative locations for would-be gentrifiers unable to afford the city centre, or whose vision of 'gentrification' is itself distinctly suburban? In the London area, for example, local centres such as Deptford and West Hampstead that lie proximate to more expensive locations (Greenwich and Hampstead) both score highly as 'home towns'.

Interestingly, the Clone Town report makes no mention of charity shops, which is conventionally regarded as a symptom of high street decline (Vaughan 2006, 291). Paddison (2000) notes that the 1990s witnessed a dramatic increase in charity shops combined with a steep decline in retail units. Even so, he argues that there is no necessary conflict between the interests of the charity and retail sector to the extent that they are seen to add value to the overall retail environment, for example, in diversifying the customer base. 
The wider significance of the Ghost Town and Clone Town report series was as propaganda in a lobbying campaign to press the UK government for a Sustainable Communities Bill. The proposed legislation would make it mandatory for the government to assist local councils and community stakeholders in drawing up local sustainability strategies and to establish amore participatory or 'bottom up’ planning process. The NEF's campaign has so far met with some success as a Sustainable Communities Bill (2007) has the support of the current government, although at time of writing (January 2008) it has not yet become law.

Does the suburban high street then, belong to the past or to the future? The case presented by the 'Ghost' and 'Clone' Town Britain reports strongly suggests that its future may be bleak. Legislation designed to empower local planners and stakeholders in supporting mixed-used streets may ameliorate the worst effects but overall there seems to be a sense of managed decline in the face of overwhelming corporate power. However, this article has argued that the relative demise of the traditional high street retailer should not be uncritically conflated with the 'death of the high street'. According to Kay (1987), the 'battle' between local independents and big business can be traced at least to the arrival of the department store in the 19th century. Since its emergence in the 18th century, the small town and suburban high street has shown that it possesses the ability to adapt to successive social and economic changes and in most cases it is still doing business - the 'retail revolutions' represented by out-of-town shopping and web-based commerce notwithstanding.

Barker (1999) cites suburban shopping centres as exciting examples of 'non-plan’; edge-city developments whose success is due to the fact that they represent an essentially 'unplanned' but optimised response to socio-economic change. In contrast, he argues that high street shops are an historical anachronism soon to be consigned to the past. However, there is something of an irony in Barker's argument when it is considered that the high street is itself a striking example of 'non-plan', emerging as a vernacular form over time as nucleated settlements expanded along historical road systems. While it is certainly the case that since PPG6 (1996) planning policy in the UK has effectively restrained the development of out-oftown shopping centres and retail parks, it is equally true that the previous phase of post-war town planning has continued to be disruptive of the unplanned 'messiness' of the traditional mixed-use street through its legacy of interventions designed to privilege functional separation in land uses and car-based transit over pedestrian accessibility. While not wishing then, to suggest that a crude laissez-faire planning regime would be beneficial to the high 
street, there is certainly a strong case to be made for planners taking care to identify the complex interrelation of socio-spatial factors that have made such essentially suburban places socially, economically and spatially viable over time. Such a precaution should facilitate against the imposition of ill-conceived or one-size-fits-all regeneration schemes. Neither should it be assumed that the full socio-economic importance of small suburban centres can be satisfactorily indexed by retail functions alone. The high street acts as a centre of consumer, commercial and communal life, a place of work and a place of leisure, as a place and as a link between places. It is the synergies between these diverse social and functional characteristics that provide the mixed-use street with the potential to adapt to social change. The future vitality and viability of the high street cannot be minutely planned for because the exact form these might take can hardly be predicted.

\section{The suburban centre as link and place}

Peter Jones has drawn on his research into the dual socio-spatial constitution of the high street as both link and place ( Jones et al. 2007) to provide amore practical design guide for planners and (sub)urban designers ( Joneses al. 2008). The guide’s authors argue that modern street design is too exclusively focused on residential uses rather than on streets as elements within an integrated urban structure, incorporating a wide range of uses at different urban scales. In a separate study devoted to this theme, Marshall argues that the principal effect of post-war modernist design principles was to sever the relationship between urban movement and urban place.

[Modernism] proposed an inverse relationship between movement and urban place. The movement would now be the movement of fast motor traffic; the urban places would become tranquil precincts [original italics]. (Marshall, 2005, 4)

Besides distorting the balance of 'link' and 'place' implied in the notion of 'dual function', the breaking of the relation between movement and place also undermines a more fundamental relationship that exists between patterns of pedestrian movement and land use; a factor that could help explain the apparent decline of economic activity on some high streets because a deserted shopping precinct is likely to prove a negative attractor to consumers and investors alike. 
Starting from a similar critique of modernism as Marshall, Hiller argues that the layout of the urban grid shapes movement flows, so that some locations in the grid are naturally movement-rich, while others are naturally movement-poor (Hillier et al. 1993). He asserts that 'natural movement' - and so ultimately the urban grid itself - influences land use patterns by attracting movement-seeking uses such as retail and restaurants to locations with high natural movement, and directing relatively non-movement seeking uses such as residence to low natural movement locations. The attracted uses then attract more movement to the high movement locations, and this in turn attracts further uses, creating a spiral of multiplier effects and resulting in an urban pattern of dense mixed-use areas, usually marked by greater regularity and smaller-sized blocks. Hiller suggests that the' fundamental city' form that emerges from these processes takes the form of a network of linked centres and sub-centres, 'live' at all scales from a couple of shops and a café through to sizeable centres and all embedded into a background of relatively homogenous residential development (Hillier 1996b).

The emphasis of both Marshall and Hillier on the relationship between urban structure and movement differs from that of an urban morphologist such as Whitehand whose primary interest is in how built form and land use are negotiated between a variety of interested agencies over time and at different stages in the economic cycle (Whitehand 1977; Whitehand and Morton 2003). While acknowledging the broad relevance of Whitehand's approach, the question of how high street locations attract movement seems more directly pertinent to understanding their vitality and viability. The approaches of Jones, Marshall and Hillier all point to the fact that movement, particularly pedestrian movement, through the influence it exerts on land use, represents the long-term dynamic factor in town centres; an essential source of adaptability to changing socio-economic conditions.

Several major research projects have recently sought to understand more about the relationship between society and the built environment in suburban and small town centres. The EPSRC's City Form research project (2003-2007) used various quality of life indicators to test the assumption that a compact, high-density and mixed-use urban form is more socially sustainable than suburban areas. Their results suggest that this is not straightforwardly the case because social cohesion appears greater in the suburbs, although it remains difficult to be definitive (Bramley et al. 2006). 
The EPSRC's (suburban) Solutions project (2004-2008) is concerned to investigate how different urban forms affect the use of neighbourhood amenities. However, Barton and Hills (2005) find little solid evidence to suggest that this relationship is significant except in the bluntest terms of car use tending to increase with distance from destination shops. Their extensive review of literature in the field of neighbourhood accessibility is highly critical of existing research into the relationship of the built environment using 'walkability' indicators, arguing that it has produced no more that 'truisms, and even those with reservation and caution'(Barton and Hills 2005, 9). A study of mixed-use suburbs in North American 'edge cities' finds that high rates of pedestrian movement tend to be associated with multifunctional environments but this is ascribed to the attraction of mixed land use itself, rather than to any particular morphological characteristic (Filion 2001).

The difficulty with these socio-spatial approaches is that they try to relate patterns of built form to movement behaviours rather too deterministically, without really addressing this relation at the human scale at which the urban grid is actually encountered - whether by pedestrian or vehicle. Broad categories of urban morphological types based on land use or density characteristics will struggle to capture the complex street level dynamics that generate movement patterns. The importance of street-level analysis is identified by Hall who, in a manner similar to Marshall, argues that achieving suburban sustainability requires an understanding of how the micro-scale relates to larger scales of movement, so that car journeys within a decentralised (i.e. multi-centred) urban model can be minimised in a ‘seamless Web’ model of transport and land use planning (Hall 1997, 142).

Returning to the 'micro' level, Vaughan's study of spatial accessibility in Borehamwood used space syntax methodology to analyse patterns of connectivity in a local street network (Vaughan 2006). Space syntax uses architectural research methods as tools for studying the spatiality of built forms and society. Space syntax analysis is concerned with systematically describing and analysing streets, squares and all open public space as a continuous system in order to measure how well-connected each street space is to its surroundings. This is done by taking an accurate street map and drawing a set of intersecting lines through all the spaces of the urban grid so that the grid is covered and all rings of circulation are completed. The resulting set of lines is called an 'axial map'. Space syntax 'integration analysis' computes all the lines and segments according to their relative depth from each other, using simple mathematical techniques. A value is assigned to each space that forms the basis for mapped 
visualisations representing the distribution of spatial accessibility in an urban area. The highest values are coloured red for the most accessible (integrated) spaces through the colour spectrum to dark blue for the least accessible (segregated) spaces (Hillier 1996a, 1999; Hillier and Hanson 1984). Vaughan argues that the advantage of space syntax over traditional morphological approaches to built form is its ability to assign a range of spatial variables at the street level against which social data at a similar resolution can be compared.

The EPSRC's Towards Successful Suburban Town Centres (2006-2009) research project is using space syntax methodology to investigate the spatial configuration of Greater London's suburban road network. Figures A-F provide a series of visualisations of Whetstone, a suburb to the north of London with medieval origins as a staging post on the Great North Road (now the A1000). Figure A shows transport infrastructure in the vicinity of Whetstone town centre including major roads ('A' roads in green, 'B' roads in yellow), car parks, railway lines and tube lines. The core town centre boundary, defined according to the DCLG's town centres study, is represented on the map by an irregular polygon with a blue outline (DCLG 2002). The dashed ellipse is an $800 \mathrm{~m}$ buffer representing an 'as the crow flies' neighbourhood of approximately 15- to 20-min walk from the town centre's core. Figure B is a space syntax 'segment map' of the same area coloured-up to visualise the 'global choice' measure. The segment map was produced from an all-line (axial) map of Greater London using a further stage of processing to subdivide the axial (road) lines at each intersection to create separate road links. The 'global choice' measure is an index of the number of times each link (segment) falls on the shortest path between each pair of segments in the Greater London road system, which represents the largest (therefore 'global') scale of analysis. In Figures BF, global choice values are displayed along a spectrum from warm colours (high choice) to cool colours (low choice). As a form of road-network analysis, choice has been shown to accurately predict major routes of vehicular and pedestrian 'through movement' (Hillier and Iida 2005). Global choice, therefore, is most useful in quantifying the extent to which the segments representing a suburban high street might be expected to constitute a relatively strong or weak link for generating vehicular movement between places at the Greater London scale. To assess the potential for the localised pedestrian movements associated with place, a smaller scale of analysis would be more appropriate. 


\section{Figures A-F: Space syntax analysis of Whetstone, Greater London showing the}

\section{global choice measure}

'Global choice' is an index of the number of times each road link (segment) falls on the shortest path between each pair of segments in a system comprising the whole Greater London area within the M25. In the visualisations in Figures B-F global choice values are displayed along a spectrum of warm to cool colours representing a scale from relatively high to relatively low choice.

a) Major roads and transport links

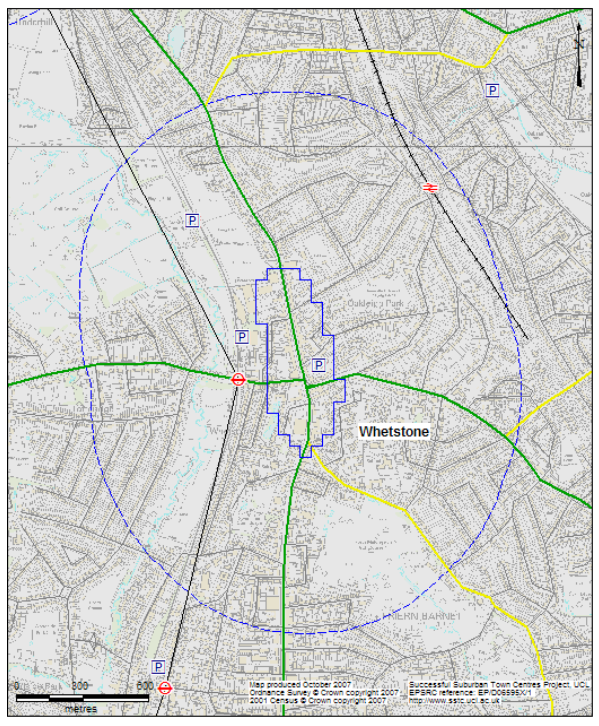

c) Office and general commercial activity

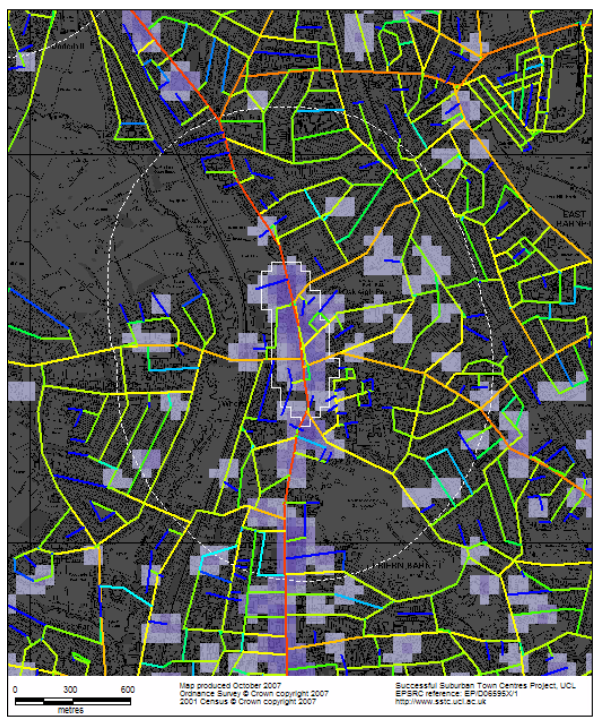

b) Space syntax analysis: global choice

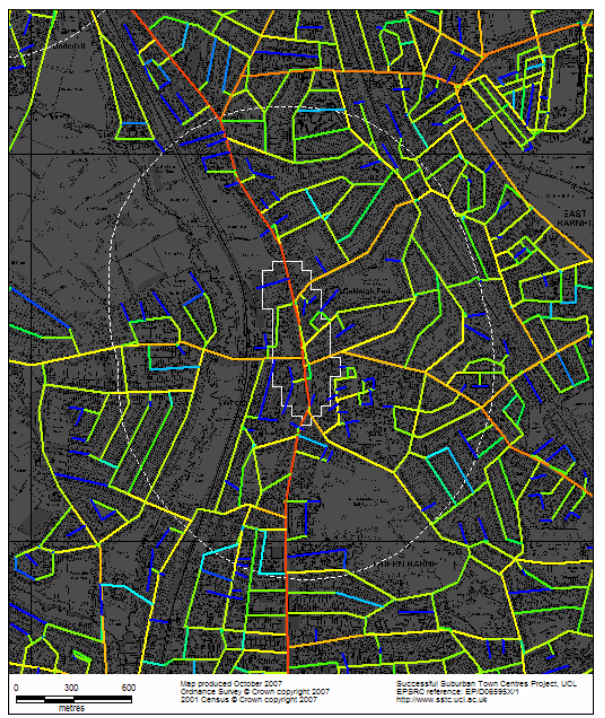

d) Industrial activity

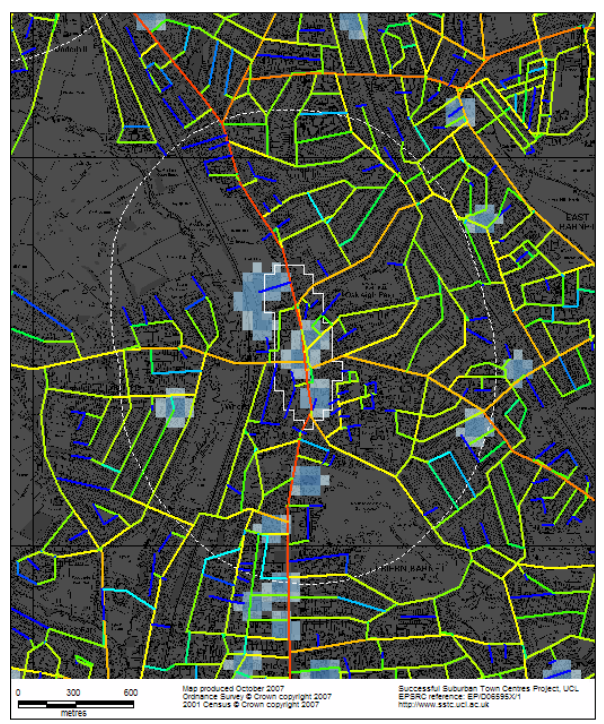


e) Retail and services activity

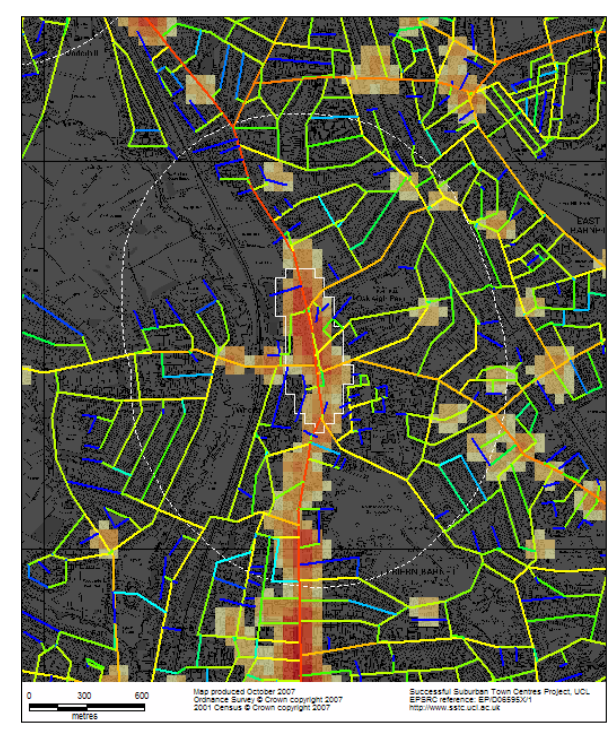

f) Community services activity

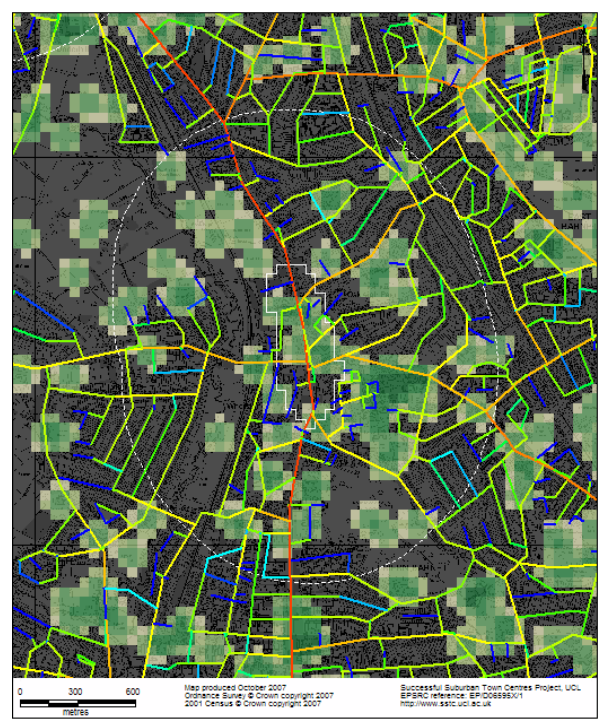

Figures C-F use Ordnance Survey Address Layer 2 postcode data ${ }^{1}$ processed in a geographical information system (GIS) to visualise four different categories of land use data as 'density surfaces' within an 800-m buffer of the Whetstone town centre. In each of the four land use categories, only those functions considered likely to generate town centre activity were included. The space syntax global choice analysis (Figure B) was then overlaid onto the four density surfaces to facilitate comparison of the spatial and functional attributes of the Whetstone area.

A comparison of Figures A-B shows how the segment map representing global choice clearly picks out in red the line of the A1000 in (green in Figure A), which is the main arterial route running north-south through Whetstone High Road. The A109 (green in Figure A), which runs east-west, and several 'B' roads (yellow in Figure A) are picked out in orange and yellow in Figure B, suggesting how these are secondary routes for through movement. In Figures C-F, office and particularly retail activities are strongly linear, industrial activity is relatively sparse and community services, including schools, public libraries and open spaces, are more evenly distributed around the town centre and the residential areas.

Figures C-F clearly show that all four kinds of land use are present in or proximate to Whetstone town centre, contributing to the overall diversity of activities present in this space 
while also extending them into the surrounding neighbourhood. The space syntax analysis in Figure B illustrates the potential for globalising 'through movement' across Whetstone town centre, an effect emphasised by the linear morphology of the town centre itself. This emphatic linearity raises the important question of what effect the presence of such a strongly articulated global movement structure may have on the possibilities for more localised, circulatory movements, because lateral connectivity with the surrounding residential area appears highly constrained, especially to the west along the line of the tube. The photograph of Whetstone High Road in Figure G illustrates how the A1000 effectively isolates pedestrian activity on either side of a busy, three-lane wide, high street. How, then, one might ask, does such a centre function as a 'place' on a day-to-day basis; to what extent are the diversity of socio-economic activities evident in this area able to generate 'buzz' or street life; do local residents access the town centre on foot or experience it mainly as a vehicular access route to their residences; what is the relationship between local morphological constraints and the strongly defined linearity of this centre; what design interventions in street layout might establish a balance between link and place more appropriate for a suburban centre such as Whetstone?

\section{Figure G: view south across Whetstone High Road illustrating difficulty of pedestrian} circulation

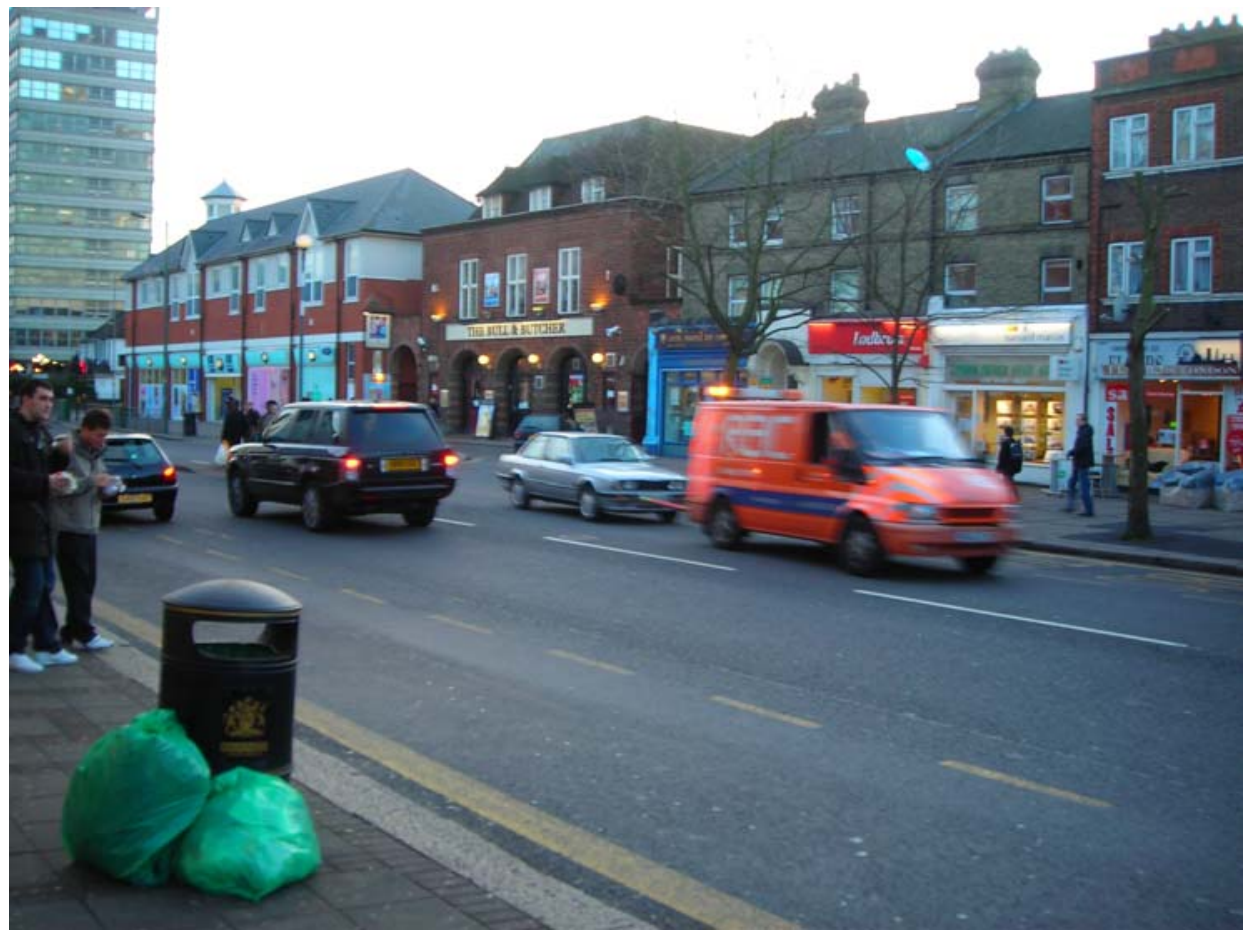


By bringing a range of space syntax analyses of land use to bear, at both smaller and larger urban scales, visualisations such as those in Figures A-F can help to generate a range of detailed hypotheses regarding the relationship between movement patterns and socioeconomic diversity in suburban town centres. These, in turn, can usefully guide and inform fieldwork-based case-studies. When considering factors favourable to the long-term vitality and viability of the suburban high street, the relationship between society and the spatiality of its built form constitutes an important source of information relating to the persistence of that high street over time. That is why this article has argued that the broad sustainability of suburban centres depends on the preservation of dynamic socio-spatial milieu in which successful adaptation may occur piecemeal within the ongoing flux of change and continuity.

\section{Conclusion}

This article has made the case for the continuing significance of the traditional suburban high street even in the age of the shopping centre and increasing web-based commerce. While sentimentalised notions of the high street that were found to have tacitly informed several areas of the literature were rejected as ahistorical, the popular image of the suburban centre as a locus of communal activity was found to still possess relevance. Attention was drawn to the problematic nature of the casual assumption that suburbia is correctly defined solely in terms of residential land uses. The relative 'invisibility' of suburban centres in this sense matters because the importance of preserving the vitality and viability of the high street can hardly be doubted if urban sprawl is to be constrained and a practical policy of achieving long-term sustainable built environments implemented. While acknowledging the largely negative impact on the high street caused by many socio-economic changes, including out-of-town retail, increased car use and ongoing corporate restructuring in the retail and banking sectors, it was also emphasised that suburban centres are not constituted monofunctionally as consumer destinations but possesses additional capabilities through which diverse forms of employment and sociability may be sustained, both on a local basis and in relation to the larger urban entity. An alternative perspective on the high street was advanced which recognised the distinctive 'dual function' of its historical constitution both as a place in its own right and as a link in a regional system of movement. This approach emphasises the significance of the high street as a particular kind of socio-spatial milieu rather than dwelling on the relative presence or absence of any particular functional category. As a consequence, 
the relation between movement and place was made central to the analysis as embodying the dynamic principle on which the ability of the high street to adapt to future socio-economic challenges depends. The emphasis on adaptability was justified on the basis of wishing to avoid simply replacing one idealised image of the traditional high street with another, perhaps equally contingent to time and place. It was argued that, before arriving at specific indicators for assessing the 'health' or 'sustainability' of a suburban town centre, it is first necessary to understand sustainability in a more fundamental sense as pertaining to those rather more generic socio-spatial factors, particularly patterns of movement, favourable to the preservation of 'vitality' and 'viability' overtime. If, over the long term, Britain’s historical suburban centres are found to be unsustainable then at what price 'Edge City'?

\section{Acknowledgements}

The research reported in this article forms part of a 36-month study funded by the EPSRC (start date 01/10/06; EPSRC reference EP/D06595X/1).

\section{Short Biographies}

Sam Griffiths is a Research Fellow on the EPSRC Towards Successful Suburban Town Centres project, based within the Space Group at the Bartlett School of Graduate Studies, University College London (UCL), UK. His research addresses the relation of urban form to processes of socio-economic change, a topic he teaches on the MSc Advanced Architectural Studies course at UCL. He holds a BA in history from the University of Sheffield, an MSc from the London School of Economics and has recently submitted his PhD in Architecture to the University of London. Together with the Towards Successful Suburban Town Centres research team, he is currently involved in preparing publications on the potential of space syntax as a methodology for historical GIS and the relevance of the suburbs to urban theory. Laura Vaughan is a Senior Lecturer in Urban and Suburban Settlement Patterns and CoDirector of the MSc Advanced Architectural Studies, Bartlett School of Graduate Studies, UCL, UK. She has written widely on urban and suburban settlement patterns, with a focus on space syntax as a method for fine grain analysis of built form. Among her recent publications

is an issue of Progress in Planning on 'The Spatial Syntax of Urban Segregation'. Currently, she is Principal Investigator on an EPSRC grant - Towards Successful Suburban Town Centres: a study of the relationship between morphology, sociability, economics and 
accessibility. She holds a BA in Design from the Bezalel Academy of Arts and Design, Jerusalem and an MSc and PhD in Architecture from the University of London. Muki Haklay is a Senior Lecturer in Geographical Information Science at the Department of Civil, Environmental and Geomatic Engineering, UCL, UK. He works on socio-economic analysis using GIS, novel analyses techniques with GIS and usability aspects of GIS. He has published articles on these subjects in Area, International Journal of Geographical Information Science, Journal of Environmental Management and Transactions in GIS. He holds a BSc in Computer Science and Geography, an MA in Geography from the Hebrew University of Jerusalem and a PhD in Geography from the University of London. Catherine Emma Jones has an MSc in GIS from UCL and spent three years working on a Knowledge Transfer Partnership between Camden Primary Care Trust and UCL Department of Geography implementing GIS and Geodemographic tools for health care. She has recently submitted her PhD in Geography to the University of London.

Notes

* Correspondence address: Sam Griffiths, Faculty of the Built Environment, Bartlett School of Graduate Studies, Department of Civil, Environmental and Geomatic Engineering, University College London, Gower Street, London WC1E 6BT, UK. E-mail: sam.griffiths@ucl.ac.uk.

${ }^{1}$ The data were extracted from Ordnance Survey Address Layer 2 data (Crown Copyright 2007) that provides a postcode address and category of activity for every postcode in the UK. The data were processed to form a functional density surface, which depicts the relative density of address points for each category of activity. The town centre boundary was taken from the DCLG's town centres study, kindly made available to the Towards Successful Suburban Town Centres project. See http://www.sstc.ucl.ac.uk/profiler/profiler.php for further examples of how the project is using these datasets in combination with space syntax. 


\section{References}

Appleyard, D. (1981). Liveable streets. Berkeley, CA: University of California Press.

APPSSG (All-Party Parliamentary Small Shops Group). (2006). High Street Britain: 2015. London: House of Commons.

Ashworth, G. J. (1997). Managing change in the city centre: the Groningen case. In: Dingsdale, A. and van Steen, P. J. M. (eds) The management of urban change in urban Europe. Groningen, The Netherlands: Groningen Studies, University of Groningen, pp. 123144.

Barker, K. (2006). Barker review of land use planning final report - recommendations. London: HMSO for HM Treasury.

Barker, P. (1999). Non-plan revisited: or the real way cities grow. Journal of Design History 12, pp. 95-110.

Barton, H., and Hills, S. (2005). Neighbourhood accessibility and social inclusion literature review and pilot study, Paper presented to the Solutions Conference, University of the West of England, Bristol, UK. [online]. Retrieved on 15 October 2007 from Solutions research project website: http://www.suburbansolutions.ac.uk/sitemapdocs.aspx

Belina, B., and Helms, G. (2003). Zero tolerance for the industrial past and other threats: policy and urban entrepreneurialism in Britain and Germany. Urban Studies 40 (9), pp. 18451867.

Bennison, D. J., and Davies, R. L. (1980). The impact of town centre shopping in Britain: their impact on traditional retail environment. Progress in Planning 14, pp. 1-104.

Borsay, P. (1989). The English urban renaissance: culture and society in the provincial town 1660-1770. Oxford, UK: Clarendon.

Bramley, G., Dempsey, N., Power, S., and Brown, C. (2006). What is 'social sustainability' and how do our existing urban forms perform in nurturing it? Paper for presentation at the Planning Research Conference Bartlett School of Planning UCL, London. [online]. Retrieved on 15 October 2007 from City Form research project website: http://www.cityform.com/publications.html.

Breheny, M. (1996). Centrists decentrists and compromisers: views on the future of urban form. In: Jenks, M., Burton, E. and Williams, K. (eds) The compact city: a sustainable urban form? London: E \& FN Spon, pp. 13-35.

Brewis, J. (2004). Sex and not the city? The aspirations of the thirty-something working woman. Urban Studies 41 (9), pp. 1821-1838.

Bromley, R. D. F., Tallon, A. R., and Thomas, C. J. (2005). City centre regeneration through residential development: contributing to sustainability. Urban Studies 42 (13), pp. 24072429. 
Bromley, R. D. F., and Thomas, C. J. (1993). The retail revolution the carless shopper and disadvantage. Transactions of the Institute of British Geographers 18, pp. 222-236.

BSCW (British Council for Shopping Centres). (2004). The smaller towns report: delivering a retailled renaissance in towns and smaller cities. London: British Council for Shopping Centres.

Champion, B. (2005). The counterurbanisation cascade in England and Wales since 1991: the evidence of a new migration dataset. Revue Belge de Geographie 1-2, pp. 85-101.

Christaller, W. (1966). Central places in southern Germany, trans. by Baskin, C. W. (original work published 1933). Englewood Cliffs, NJ: Prentice-Hall.

City Form (2003-2007). EPSRC sponsored academic research project reference GR/S20529/01. [online]. Retrieved on 15 October 2007 from http://wwwcity formcom/indexhtml.

Clapson, M. (2003). Suburban century: social change and urban growth in England and the USA. Oxford, UK: Berg.

Dawson, J. A. (1988). Futures for the high street. Geographical Journal 154, pp. 1-12.

DCLG (Department of Communities and Local Government). (2002). Town centre boundaries and statistics for England and Wales. [online]. Retrieved on 15 October 2007 from http://6273191157/towncent/2002/entryhtm.

DETR (Department of the Environment, Transport and the Regions). (1996). Planning Policy Guidance (PPG6) town centre and retail developments revised. London: HMSO.

DETR/Welsh Office. (1993). Planning Policy Guidance (PPG6) town centre and retail developments. London: HMSO.

Duany, A., Plater-Zyberk, E., and Speck, J. (2000). Suburban nation: the rise of sprawl and the decline of the American dream. New York: North Point Press.

Echenique, M., and Homewood, R. (2003). The future of suburbs and exurbs. Cambridge, UK: Independent Transport Commission. [online]. Retrieved on 15 October 2007 from http:// www.trg.soton.ac.uk/itc/reports.htm

Felstead, A., Jewson, N., Phizacklea, A., and Walters, A. (2001). Working at home: statistical evidence for seven key hypotheses. Work Employment \& Society 152, pp. 215-231.

Filion, P. (2001). Suburban mixed-use centres and urban dispersion: what difference do they make? Environment and Planning A 33, pp. 141-160.

Fowler, C. (1998). Changes in provincial retail practice during the eighteenth century with particular reference to central-southern England. Business History 40, pp. 37-54. 
Francis, A., and Wheeler, J. (2006). One planet living in the suburbs. Godalming, UK: BioRegional for the World Wildlife Fund.

Garreau, J. (1992). Edge city: life on the new frontier. New York: Anchor Books.

Giles, J. (2004). The parlour and the suburb: domestic identities, class, femininity and modernity. Oxford, UK: Berg.

GLA (Greater London Authority). (2007). Semi-detached: reconnecting London's suburbs. London: London Assembly Planning and Spatial Development Committee for the GLA.

Gransby, D. M. (1988). The coexistence of high street and out-of-town retailing from a retailing perspective. Geographical Journal 154, pp. 13-16.

Guy, C. M. (1988). Controlling new retail spaces: the impress of planning policies in Western Europe. Urban Studies 35 (5-6), pp. 953-979.

Guy, C. M., and Lord, J. D. (1993). Transformation in the city centre. In: Bromley, D. F. and Thomas, C. J. (eds) Retail change: contemporary issues. London: UCL Press, pp. 88-108.

Gwilliam, M., Bourne, C., Swain, C., and Prat, A. (1999). Sustainable renewal of suburban areas. London: Civic Trust for the Joseph Rowntree Foundation.

Hall, P. (1997). The future of the metropolis and its form. Regional Studies 31, pp. 211-220.

Hall, P., Marshall, S., and Lowe, S. (2001). The changing urban hierarchy in England and Wales 1913-1998. Regional Studies 359, pp. 775-807.

Harris, R., and Larkham, P. J. (1999). Suburban foundation, form and function. In: Harris, R. and Larkham, P. J. (eds) Changing suburbs foundation, form and function. London: E \& FN Spon, pp. 1-31.

Hillier, B. (1996a). Space is the machine. Cambridge, UK: Cambridge University Press.

—_ (1996b). Cities as movement economies. Urban Design International 11, pp. 47-60.

- (1999). Centrality as a process: accounting for attraction inequalities in deformed grids Urban Design International 4, pp. 107-127.

Hillier, B., and Hanson, J. (1984). The social logic of space. Cambridge, UK: Cambridge University Press.

Hillier, B., and Iida, S. (2005). Network effects and psychological effects: a theory of urban movement. The 5th International Space syntax Symposium Proceedings. Delft, The Netherlands: Techne Press, pp. 553-564.

Hillier, B., and Sahbaz, O. (2005). High resolution analysis of crime patterns in urban street networks: an initial statistical sketch from an ongoing study of a London borough. The 5th 
International Space Syntax Symposium Proceedings. Delft, The Netherlands: Techne Press, pp. 451-477.

Hillier, B., Penn, A., Hanson, J., Grajewski, T., and Xu, J. (1993). Natural movement: or configuration and attraction in urban pedestrian movement. Environment and Planning B 20, pp. 29-66.

Hinchcliffe, T. (2005). Elusive suburbs endless variation. Journal of Urban History 316, pp. 899-906.

Hubbard, P. (2002). Screen-shifting: consumption riskless risks and the changing geographies of cinema. Environment and Planning A 34, pp. 1239-1258.

In Suburbia Partnership. (2005). In suburbia: delivering sustainable communities. Winchester, UK: Civic Trust for Hampshire County Council.

—_. (2002). In suburbia. Winchester, UK: Hampshire County Council.

Jacobs, J. (1961). The death and life of great American cities. New York: Random House.

Jones, P., Boujenko, N., and Marshall, S. (2008). Link \& place: a guide to street planning and design. London: Landor Publishing.

Jones, P., Roberts, M., and Morris, L. (2007). Rediscovering mixed-use streets: the contribution of local high streets to sustainable communities. Bristol, UK: Policy Press for the Joseph Rowntree Foundation.

Kay, W. (1987). The battle for the high street. London: Piatkus.

Kochan, A. (2007). Achieving a suburban renaissance: the policy challenges. London: Town and Country Planning Association for the Joseph Rowntree Foundation.

Lang, E. (2003). Edgeless cities: exploring the elusive metropolis. Washington, DC:

Brookings Institution Press.

Lees, L., Slater, T., and Wyly, E. (2008). Gentrification. New York: Routledge.

Lloyd, D., Haklay, M., Thurstain-Goodwin, M., and Tobón, C. (2003). Visualising structure in new data systems. In: Longley, P. and Batty, M. (eds) Advanced spatial analysis. Redland, CA: ESRI Press, pp. 267-286.

Madanipour, A. (2003). Public and private spaces of the city. London: Routledge.

Madden, J. F. (1981). Why women work closer to home. Urban Studies 18 (2), pp. 181-194.

Maguire, S., Tendwr, J., and Edwards, M. (2004). Intra-urban polycentric development: suburban trajectories. ODPM New Horizons Research Programme Futures-Orientated Review Series 2003-2004. [online]. Retrieved on 15 October 2007 from http://www.communities.gov.uk/ documents/corporate/pdf/142772 
Marshall, S. (2005). Street patterns. Abingdon, UK: Spon Press.

- (2006). The emerging 'silicon savannah': from old urbanism to new suburbanism. Built Environment 32, pp. 267-280.

McDowell, L., Ward, K., Perrons, D., Ray, K., and Fagan, C. (2006). Place, class and local circuits of reproduction: exploring the social geography of middle-class childcare in London. Urban Studies 43 (12), pp. 2163-2183.

NEF (New Economics Foundation). (2003). Ghost town Britain II: death on the high street. London: NEF.

- (2005). Clone town Britain: the loss of local identity on the nation's high streets. London: NEF.

Neyland, D. (2004). Closed circuits of interaction? Information Communication and Society 72, pp. 252-271.

Oc, T., and Tench, S. (1993). Planning and shopping security. In: Bromley, D. F. and Thomas, C. J. (eds) Retail change: contemporary issues. London: UCL Press, pp. 153-170.

ODPM (Office of the Deputy Prime Minister). (2002). Living places: cleaner, safer greener. London: HMSO.

—. (2003). Sustainable communities: building for the future. London: HMSO.

- (2005). Planning Policy Statement 6: planning for town centres. London: The Stationery Office.

Paddison, A. (2000). Charity shops on the high street: complementarity or unwanted neighbour? International Journal of Nonprofit and Voluntary Sector Marketing 52, pp. 161172.

Phelps, N. A., Parsons, N., Ballas, D., and Dowling, A. (2006). Post-suburban Europe: planning and politics at the margins of Europe's capital cities. Basingstoke, UK: Palgrave Macmillan.

Potts, G., Falk, N., and Kochan, B. (2007). London's suburbs - unlocking their potential. A report accompanying the London Assembly's enquiry into London Suburbs. London: BURA \& URBED.

Raco, M. (2003). Remaking place and securitising space: urban regeneration and the strategies, tactics and practices of policing in the UK. Urban Studies 40 (9), pp. 1869-1887. Ravenscroft, N. (2000). The Vitality and viability of town centres. Urban Studies 37 (13), pp. 2533-2549.

Reynolds, J. and Schiller, R. (1992). A new classification of shopping centres in Great Britain using multiple branch numbers. Journal of Property Research 9 (2), pp. 122-160. 
Rowley, G. (1993). Prospects for the central business district. In: Bromley, D. F. and Thomas, C. J. (eds) Retail change: contemporary issue. London: UCL Press, pp. 110-125.

Rowley, T. (2006). The English landscape in the twentieth century. London: Hambledon Continuum.

Rydin, Y. (1999). Can we talk ourselves into sustainability? The role of discourse in the environmental policy process. Environmental Values 84, pp. 467-484.

SCB (Sustainable Communities Bill). (2007). HMSO for the House of Lords and House of Commons, London. [online]. Retrieved on 15 October 2007 from http://www.publications.parliament.uk/pa/pabills/200607/sustainable_communities.htm.

Schiller, R. (1988). Retail decentralisation - a property view. Geographical Journal 154, pp. 17-19.

Solutions (Sustainability of Land Use and Transport in Outer Neighbourhoods). (2004-2008). EPSRC sponsored academic research project reference GR/S90874/01. [online]. Retrieved on 15 October 2007 from http://wwwsuburbansolutionsacuk/.

Stobart, J., Hann, A., and Morgan, V. (2007). Spaces of consumption: leisure and shopping in the English town c1680-1830. New York: Routledge.

Thorns, D. C. (1972). Suburbia. London: MacGibbon and Kee.

Tiesdell, S. (2002). The New Urbanism and English residential design guidance: a review. Journal of Urban Design 7, pp. 353-376.

Tolley, R., and Turton, B. (1995). Transport systems, policy and planning: a geographical approach. Harlow, UK: Longman.

Towards Successful Suburban Town Centres. (2006-2009). EPSRC sponsored academic research project reference EP/D06595X/1. [online]. Retrieved on 15 October 2007 from http://www.sstc.ucl.ac.uk/.

URBED (Urban and Economic Development Group). (1994). Vital and viable town centres: meeting the challenge. London: HMSO.

- (2002). A city of villages: promoting a sustainable future for London's suburbs. London: Greater London Authority.

(2004). Neighbourhood revival: towards more sustainable suburbs in the South East. London: South East England Regional Assembly.

UTF (Urban Task Force). (1999). Towards an urban renaissance: final report of the Urban Task Force chaired by Lord Rogers of Riverside. London: DETR. 
- (2005). Towards a strong urban renaissance: an independent report by members of the Urban Task Force chaired by Lord Rogers of Riverside. [online]. Retrieved on 15 October 2007 from http://www.urbantaskforce.org/UTF_final_report.pdf

Vaughan, L. (2006). Making connections: the case of Borehamwood. Built Environment 32, pp. 281-297.

Westlake, T. (1993). The disadvantaged consumer, problems and policies. In: Bromley, D. F. and Thomas, C. J. (eds) Retail change: contemporary issue. London: UCL Press, pp. 172191.

Whitehand, J. W. R. (1977). The basis for an historico-geographical theory of urban. Transactions of the Institute of British Geographers, New Series 2 (3), pp. 400-416.

Whitehand, J. W. R., and Carr, C. M. H. (2001). Twentieth-century suburbs: a morphological approach. London: Routledge.

Whitehand, J. W. R., and Morton, N. J. (2003). Fringe belts and the recycling of urban land:30, pp. 819-839.

Whyte, W. H. (1980). The social life of small urban spaces. Washington, DC: Conservation Foundation.

Wrigley, N. (2002). 'Food deserts' in British cities: policy context and research priorities. Urban Studies 39 (11), pp. 2029-2040.

Wrigley, N., and Lowe, M. (eds) (1996). Retailing, consumption and capital: towards the new retail geography. Harlow, UK: Longman. 